\title{
Analisis Faktor yang Berpengaruh dalam Swamedikasi Antibiotik pada Ibu Rumah Tangga di Kelurahan Kajen Kebupaten Pekalongan
}

\section{Ady Restiyono*)}

*) Magister Promosi Kesehatan Universitas Diponegoro Semarang

Email: ady_farma@yahoo.com

\begin{abstract}
ABSTRAK
Swamedikasi adalah cara yang telah biasa dilakukan masyarakat terutama ibu rumah tangga dalam pengobatan beberapa penyakit ringan sekarang ini. Antibiotik merupakan salah satu obat yang sering digunakan secara tidak rasional dalam swamedikasi oleh ibu rumah tangga. Penelitian ini bertujuan untuk menganalisis faktor apa saja yang berpengaruh dalam swamedikasi antibiotik pada ibu rumah tangga di Kelurahan Kajen Kabupaten Pekalongan. Penelitian dilakukan secara analitik dengan pendekatan cross sectional. Dengan menggunakan tekhnik proportional random sampling, sebanyak $300 \mathrm{ibu}$ rumah tangga sebagai sample telah diteliti, dan menunjukkan bahwa lebih banyak ibu rumah tangga yang tidak melakukan swamedikasi antibiotik (59\%) dibandingkan yang melakukan swamedikasi antibiotik. Faktor yang paling berpengaruh dalam swamedikasi antibiotik pada ibu rumah tangga adalah pengetahuan tentang antibiotik $(\mathrm{OR}=5.307$, $\mathrm{p}=0,000$ ) sehingga pengetahuan yang baik memiliki kemugkinan 5.307 kali tidak melakukan swamedikasi antibiotik, serta sumber informasi $(\mathrm{OR}=29,94, \mathrm{p}=0.0005)$ sehingga memiliki sumber informasi yang baik memiliki kemungkinan 29,94 kali tidak melakukan swamedikasi antibiotik.
\end{abstract}

Kata kunci: swamedikasi, antibiotik, ibu rumah tangga

\section{ABSTRACT}

Swamedication had been known in society especially housewives for treating some mild disseases. Antibiotic is one of the drugs which is often used irrationally by housewives. This research aims to analyze factors influence in antibiotic swamedication by hosewives at Kelurahan Kajen Kabupaten Pekalongan. This research was done analitically with cross sectional approach. By using proportional random sampling technique, 300 hosewives as sample has been investigated and showes that more house wives are not doing antibiotics swamedication (59\%) than do. The most influential factors in antibiotics swamedication by housewives are knowladge about antibiotic (OR=5.307, p=0,000) so, good knowladge likely 5.307 times not doing antibiotic swamedication, and source of information of antibiotics $(O R=29,94, p=0.0005)$ so, good source of information of antibiotics likely 29.94 times not doing antibiotic swamedication.

Keywords: swamedication, antibiotic, housewife

\section{PENDAHULUAN}

Obat merupakan komponen yang penting karena diperlukan dalam sebagian besar upaya kesehatan baik untuk menghilangkan gejala dari suatu penyakit, obat juga dapat mencegah penyakit bahkan obat juga dapat menyembuhkan penyakit.

Pengobatan sendiri adalah penggunaan obat oleh masyarakat untuk tujuan pengobatan sakit ringan (minor illnesses), tanpa resep atau intervensi 
dokter. Pengobatan sendiri yang sesuai aturan adalah apabila cara menggunakan obat sesuai dengan keterangan yang tercantum dalam kemasan. Selain mempunyai keuntungan, pengobatan sendiri yang tidak sesuai aturan selain dapat membahayakan kesehatan juga pemborosan waktu dan biaya karena harus melanjutkan upaya pencarian pengobatan (Shankar, 2002).

Swamedikasi merupakan upaya pengobatan yang dilakukan sendiri, biasanya dilakukan untuk mengatasi keluhan-keluhan dan penyakit ringan yang banyak dialami masyarakat, seperti demam, nyeri, pusing, batuk, influenza, sakit maag, cacingan, diare, penyakit kulit dan lain-lain. Swamedikasi menjadi alternatif yang diambil masyarakat untuk meningkatkan keterjangkauan pengobatan masyarakat memerlukan pedoman yang terpadu agar tidak terjadi kesalahan pengobatan (medication error). Apoteker sebagai salah satu profesi kesehatan sudah seharusnya berperan sebagai pemberi informasi (drug informer) khususnya untuk obat-obat yang digunakan dalam swamedikasi. Obat-obat yang termasuk dalam golongan obat bebas dan bebas terbatas relatif aman digunakan untuk pengobatan sendiri atau swamedikasi (KepMenkes RI, 2002).
Pemilihan jenis obat yang akan digunakan perlu memperhatikan gejala atau keluhan penyakit, kondisi khusus misalnya hamil, menyusui, bayi, lanjut usia, diabetes mellitus, hipertensi, pengalaman alergi atau reaksi yang tidak diinginkan terhadap obat tertentu, cara pemakaian, efek samping dan interaksi obat yang dapat dibaca pada etiket atau brosur obat. Pemilihan jenis obat disesuaikan dengan gejala penyakit dan tidak ada interaksi dengan obat yang sedang diminum (Djunarko dan Hendrawati, 2011)

Antibiotik bukan obat berbahaya, tetapi obat-obat ini hanya boleh diresepkan jika infeksi bakteri terbukti ada. Namun masih banyak masyarakat yang cenderung melakukan swamedikasi antibiotik untuk penyakit yang dideritanya.

Menurut data BPS tahun 2011 masyarakat Indonesia yang melakukan pengobatan sendiri (swamedikasi) dari tahun 2007 sampai 2010 jumlahnya cukup besar dan meningkat terus dibandingkan dengan yang melakukan pengobatan rawat jalan yaitu pada tahun 2007 . Persentase masyarakat yang melakukan swamedikasi adalah 65,01\%, tahun 2008, $65,59 \%$, tahun $200968,41 \%$ dan tahun 2010 68,71\%. Sedangkan data yang melakukan pengobatan rawat jalan dari 
tahun 2007 sampai 2010 yaitu pada tahun 2007 persentase masyarakat yang melakukan pengobatan rawat jalan adalah 44,14\%, tahun $200844,37 \%$, tahun 2009 44,74\% dan tahun $201043,99 \%$.

Swamedikasi antibiotik memiliki dampak secara medis, yaitu dapat terjadi resistensi yang dapat memperparah penyakit. Karena tidak semua penyakit memerlukan antibiotik. Fenomena swamedikasi antibiotik tidak hanya di perkotaan saja tetapi di desa pun sama. Posisi desa Kajen yaitu di pertengahan antara kota dengan pedesaan.

Hasil survey pada masyarakat di Kecamatan Kajen pada tahun 2011 cenderung melakukan pengobatan sendiri sehingga penjualan obat bebas dan obat bebas terbatas di apotek, toko obat dan warung meningkat $30 \%$. Peningkatan penjualan obat bebas dan obat bebas sangat dipengaruhi iklan di televisi dan perubahan musim. Apotek di wilayah Kajen pada waktu melayani penjualan obat bebas dan obat bebas terbatas sudah disertai infomasi tentang pemilihan obat sesuai dengan kondisi pasien, cara minum, aturan minum, cara penyimpanan dan pemilihan obat yang terjangkau oleh pasien, sehingga ibu-ibu rumah tangga sudah mulai beralih untuk membeli obat di apotek. Apotek di Kajen kebanyakan sudah mempunyai standar pelayanan ke pasien sehingga apoteker di apotek sudah berperan aktif dalam memberikan KIE kepada masyarakat tetapi masih perlu ditingkatkan. Standar operasional pelayanan yang ada di Apotek di wilayah kajen di terapkan mulai dari pemesanan obat, penerimaan, penyimpanan, pelayanan obat kepada pasien dengan pemilihan obat yang tepat.

Pada perkembangannya saat ini di desa Kajen terdapat apotek-apotek baru berdiri. Hal ini juga dapat menandakan bahwa kebutuhan masyarakat terhadap ketersediaan pelayanan swamedikasi meningkat.

Oleh karena itu sangat penting untuk menganalisis factor-faktor yang mempengaruhi swamedikasi antibiotik pada ibu rumah tangga di desa Kajen Kabupaten Pekalongan.

\section{METODE}

Metode penelitian yang digunakan adalah penelitian analitik dengan rancangan survey cross sectional.

Populasi dalam penelitian ini adalah seluruh ibu rumah tangga di Kelurahan Kajen Kabupaten Pekalongan sebanyak 1.198 orang. Jumlah sampel yang ditentukan sebanyak 300 orang diambil dengan teknik proportional random sampling. 
Penelitian data menggunakan data primer. Pengumpulan data menggunakan wawancara langsung terhadap responden dengan menggunakan alat pengumpulan data yang berupa kuesioner.

Pengolahan data meliputi editing, scoring, coding, entry data, tabulating dan processing data. Analisis data meliputi:

1) Analisa univariat

Analisa univariat menggunakan analisa deskriptif untuk menggambarkan setiap variabel yang diteliti secara terpisah.

2) Analisa bivariat
Analisa bivariat dilakukan melalui analisa tabulasi silang crosstabs dengan uji Chi Square $(\alpha=0.05)$.

3) Analisa multivariat

Analisa multivariat menggunakan analisa regresi logistik untuk menentukan variabel yang dominan dalam pola hubungan antara variabel bebas dengan variabel terikat.

\section{HASIL}

\section{Analisis Univariat}

Hasil dari analisis univariat terhadap semua variabel dalam penelitian ini dapat dilihat pada tabel berikut:

Tabel 1. Hasil Analisis Univariat

\begin{tabular}{|c|c|c|c|}
\hline Variabel & Kategori & Frekuensi & Persentase \\
\hline \multirow[t]{2}{*}{ 1. Usia } & Dewasa Muda & 169 & 56.3 \\
\hline & Dewasa Lanjut & 131 & 43.7 \\
\hline \multirow[t]{2}{*}{ 2. Pendidikan } & Dasar (SD-SMP) & 9 & 3 \\
\hline & PTinggi (SMA-PT) & 291 & 97 \\
\hline \multirow[t]{2}{*}{ 3. Jumlah anggota keluarga } & Kurang dari 3 orang $(<3)$ & 73 & 24,3 \\
\hline & Lebih dari 3 orang $(\geq 3)$ & 227 & 75,7 \\
\hline \multirow[t]{2}{*}{ 4. Pekerjaan } & Tidak Bekerja & 266 & 88,7 \\
\hline & Bekerja & 34 & 11,3 \\
\hline \multirow{2}{*}{ 5. Pendapatan } & Kurang dari Rp. 1.100.000 & 20 & 6,7 \\
\hline & Lebih dari Rp. 1.100 .000 & 280 & 93,3 \\
\hline \multirow{2}{*}{$\begin{array}{l}\text { 6. Pengetahuan tentang } \\
\text { antibiotik }\end{array}$} & Baik & 181 & 60.3 \\
\hline & Kurang Baik & 119 & 39,7 \\
\hline \multirow{2}{*}{$\begin{array}{l}\text { 7. Alasan pemilihan } \\
\text { antibiotik }\end{array}$} & Baik & 164 & 54,7 \\
\hline & Kurang Baik & 136 & 45,3 \\
\hline \multirow[t]{2}{*}{ 8. Sumber informasi } & Baik & 181 & 60,3 \\
\hline & Kurang Baik & 119 & 39,7 \\
\hline \multirow[t]{2}{*}{ 9. Swamedikasi } & Melakukan & 123 & 41 \\
\hline & Tidak melakukan & 177 & 59 \\
\hline
\end{tabular}


Tabel 1 di atas menunjukkan bahwa berdasarkan karakteristik responden diketahui bahwa sebagian besar responden berumur dewasa muda (56,3\%), berpendidikan tinggi (97\%), memiliki jumlah anggota keluarga lebih dari 3 orang $(75,7 \%)$, tidak memiliki pekerjaan $(88,7 \%)$ dan berpendapatan lebih dari $\mathrm{Rp}$. 1.100.000,- (93,3\%).

Selanjutnya dari tabel 1 juga diketahui bahwa responden memiliki pengetahuan yang baik mengenai antibiotic $(60,3 \%)$, memiliki alasan yang baik dalam memilih antibiotic (54,7\%), memiliki sumber informasi yang baik $(60,3 \%)$ serta cenderung tidak melakukan swamedikasi (59\%).

\section{Analisis Bivariat}

Kesimpulan hasil uji bivariat masing-masing variabel independen terhadap variabel dependen dapat dilihat pada rangkuman seperti pada tabel di bawah ini:

Tabel 2. Hasil Analisis Bivariat

\begin{tabular}{|l|c|c|}
\hline \multicolumn{1}{|c|}{ Variabel Bebas } & Nilai p & Keterangan \\
\hline 1. Usia & 0.112 & $\begin{array}{l}\text { Tidak ada } \\
\text { hubungan }\end{array}$ \\
\hline 2. Pendidikan & 0.831 & $\begin{array}{l}\text { Tidak ada } \\
\text { hubungan }\end{array}$ \\
\hline 3. Jumlah anggota keluarga & 0.165 & $\begin{array}{l}\text { Tidak ada } \\
\text { hubungan }\end{array}$ \\
\hline 4. Pekerjaan & 0.982 & $\begin{array}{l}\text { Tidak ada } \\
\text { hubungan }\end{array}$ \\
\hline 5. Pendapatan & 0.572 & $\begin{array}{l}\text { Tidak ada } \\
\text { hubungan }\end{array}$ \\
\hline 6. Pengetahuan tentang antibiotik & 0.000 & Ada hubungan \\
\hline 7. Alasan pemilihan antibiotik & 0.000 & Ada hubungan \\
\hline $\begin{array}{l}\text { 8. Sumber informasi pemilihan } \\
\text { antibiotik }\end{array}$ & 0.000 & Ada hubungan \\
\hline
\end{tabular}

Berdasarkan tabel 2 ditunjukkan bahwa diantara 8 variabel bebas yang diteliti, terdapat 3 variabel yang berhubungan secara statistik dengan swamedikasi antibiotik pada ibu rumah tangga di Kelurahan Kajen Kabupaten Pekalongan, yaitu pengetahuan tentang antibiotik, alasan pemilihan antibiotik dan sumber informasi pemilihan antibiotik.

\section{Analisis Multivariat}

Hasil analisis multivariat menggunakan regresi logistik dengan metode Backward LR menunjukkan hasil sebagai berikut: 
Tabel 3. Hasil Analisis Multivariat

\begin{tabular}{|l|c|c|c|c|c|c|c|c|}
\hline \multirow{2}{*}{\begin{tabular}{c}
\multirow{2}{*}{$\begin{array}{c}\text { Variabel } \\
\text { Independen }\end{array}$} \\
\cline { 2 - 9 }
\end{tabular}} & \multicolumn{6}{|c|}{ Praktik Pencegahan Infeksi HIV Pasca Pajanan (PEP) } \\
\hline $\begin{array}{l}\text { Pengetahuan } \\
\text { antibiotik }\end{array}$ & 1,669 & 0,389 & 18,451 & 1 & 0,000 & 5,307 & 2,478 & 11,366 \\
\hline Sumber informasi & 3,399 & 0,388 & 54,256 & 1 & 0,000 & 29,940 & 13,990 & 64,073 \\
\hline Konstanta & $-2,514$ & 0,341 & 54,256 & 1 & 0,000 & 0,081 & & \\
\hline
\end{tabular}

Dari tabel 3 di atas dapat dijelaskan sebagai berikut:

a. Nilai adjusted OR atau exp (B) variabel sumber informasi pemilihan antibiotik sebesar 29,94 dengan $\mathrm{p}=$ $0.000(\mathrm{p}<0,05)$ berarti yang memiliki sumber informasi baik mempunyai kemungkinan 29,94 kali tidak melakukan swamedikasi antibiotik dibandingkan dengan yang memiliki sumber informasi kurang baik.

b. Nilai adjusted OR atau exp (B) variabel pengetahuan tentang antibiotik sebesar 5.307 dengan $\mathrm{p}=$ $0.000(\mathrm{p}<0,05)$, berarti pengetahuan yang baik mempunyai kemungkinan 5.307 kali tidak melakukan swamedikasi antibiotik dibandingkan dengan pengetahuan yang kurang baik.

\section{PEMBAHASAN}

\section{Usia}

Usia merupakan lama hidup yang dihitung sejak dilahirkan. Semakin bertambah umur seseorang, semakin bertambah pula daya tanggapnya. Melalui perjalanan usianya semakin dewasa individu yang bersangkutan akan melakukan adaptasi perilaku terhadap lingkungan.

Semakin cukup umur, tingkat kematangan dan kekuatan seseorang akan lebih matang dalam berpikir dan bekerja. Pada usia yang semakin tua maka seseorang semakin banyak pengalaman sehingga pengetahuannya semakin bertambah. Karena pengetahuannya banyak maka seseorang akan lebih siap dalam menghadapi sesuatu (Notoatmodjo, 2003)

Berdasarkan hasil penelitian diperoleh nilai $\mathrm{p}=0,112$ maka dapat disimpulkan tidak terdapat hubungan usia dengan swamedikasi antibiotik 
pada ibu rumah tangga di Kelurahan Kajen Kabupaten Pekalongan. Hal ini menunjukkan bahwa swamedikasi antibiotik pada ibu rumah tangga tidak terkait dengan usia para ibu, meskipun seharusnya responden dengan usia dewasa lebih cenderung untuk tidak melakukan swamedikasi antibiotik secara sembarangan karena kedewasaannya dalam berfikir.

\section{Pendidikan}

Pendidikan adalah setiap usaha, pengaruh, perlindungan dan bantuan yang diberikan kepada seseorang. Konsep dasar pendidikan adalah suatu proses belajar, jadi semakin tinggi pendidikan ibu maka semakin mudah pula menerima informasi, sehingga banyak pengetahuan yang dimiliki, sebaliknya pendidikan yang kurang akan menghambat perkembangan sikap seseorang terhadap nilai-nilai baru yang diperkenalkan. Hal demikian dikemukakan juga oleh Notoatmodjo (2003) bahwa pendidikan yang rendah dapat menyebabkan timbulnya pola pemikiran yang irasional dan adanya kepercayaan-kepercayaan kepada takhayul. Ibu yang seperti ini akan sulit menerima hal-hal baru.

Berdasarkan hasil penelitian dapat disimpulkan tidak terdapat hubungan pendidikan dengan swamedikasi antibiotik pada ibu rumah tangga di
Kelurahan Kajen Kabupaten

Pekalongan. Pendidikan sebagian besar ibu adalah SMA, meskipun tingkat pendidikan yang dimiliki sudah cukup memadai, namun kurangnya sosialisasi mengenai swamedikasi antibiotik menjadikan ibu rumah tangga tidak memahami dengan baik mengenai swamedikasi itu sendiri, sehingga masih banyak yang melakukan swamedikasi secara sembarangan.

\section{Jumlah Anggota Keluarga}

Jumlah anggota keluarga terkait dengan tingkat pengeluaran dalam suatu keluarga. Semakin besar jumlah anggota keluarga maka semakin besar pula pengeluarannya yang pada akhirnya mempengaruhi sebuah keluarga dalam memenuhi kebutuhan, terutama kebutuhan kesehatan.

Hasil penelitian diperoleh nilai $\mathrm{p}=$ 0,165 maka dapat disimpulkan tidak terdapat hubungan jumlah anggota keluarga dengan swamedikasi antibiotik pada ibu rumah tangga di Kelurahan Kajen Kabupaten Pekalongan. Besar anggota keluarga tidak berpengaruh banyak pada keputusan ibu rumah tangga dalam praktik swamedikasi antibiotik, mengingat sebagian besar ibu rumah tangga hanya mempertimbangkan faktor kepraktisan saja dalam melakukan swamedikasi antibiotik. 
Faktor-faktor yang Berpengaruh....... (Ady Restiyono)

\section{Pekerjaan}

Pekerjaan adalah salah satu upaya untuk mendapatkan penghasilan, dengan bekerja maka akan meningkatkan penghasilan sehingga dapat memenuhi kebutuhan dan meningkatkan kesejahteraan. Selain mendapatkan penghasilan, lingkungan pekerjaan akan memberikan pengalaman dan pengetahuan baik secara langsung maupun tidak langsung. Pengalaman yang kurang baik mendorong seseorang akan berusaha untuk melupakan, namun jika pengalaman terhadap obyek tersebut menyenangkan maka secara psikologis timbul kesan yang sangat mendalam dan membekas dalam emosi kejiwaannya, dan akhimya dapat pula membentuk sikap positif dalam kehidupannya.

Berdasarkan hasil penelitian tidak terdapat hubungan pekerjaan dengan swamedikasi antibiotik pada ibu rumah tangga di Kelurahan Kajen Kabupaten Pekalongan. Pekerjaan tidak mempengaruhi keputusan untuk melakukan swamedikasi antibiotik atau tidak. Ibu rumah tangga yang bekerja cenderung lebih banyak melakukan swamedikasi, mengingat pengobatan dengan swamedikasi dirasa lebih praktis dan tidak mengganggu aktivitas pekerjaan.

\section{Pendapatan}

Pendapatan merupakan penghasilan seseorang untuk membiayai kehidupan pribadinya dan keluarganya. Semakin besar pendapatan seseorang maka semakin sejahtera kehidupan seseorang. Namun demikian, pendapatan tidak mempengaruhi praktik swamedikasi pada ibu rumah tangga. Berdasarkan hasil penelitian disimpulkan terdapat hubungan pekerjaan dengan swamedikasi antibiotik pada ibu rumah tangga di Kelurahan Kajen Kabupaten Pekalongan.

\section{Pengetahuan tentang Antibiotik}

Pengetahuan adalah merupakan hasil dari tahu, yang terjadi setelah orang melakukan penginderaan terhadap suatu obyek tertentu. Penginderaan terjadi melalui panca indera manusia, yakni indra penglihatan, pendengaran, penciuman, rasa dan raba. Sebagian besar pengetahuan manusia diperoleh melalui mata dan telinga (Notoatmodjo, 2010).

Persentase responden sebagian besar memiliki pengetahuan yang baik tentang antibiotik 54.7\%. Dengan jumlah responden yang melakukan swamedikasi sebanyak $16.6 \%$ sedangkan jumlah responden yang tidak melakukan swamedikasi sebanyak 83.4\%.. Analisa bivariat menunjukkan bahwa dengan nilai $\alpha=0,05$ diperoleh 
nilai $\mathrm{p}=0,000$ maka dapat disimpulkan terdapat pengaruh Pengetahuan Tentang Antibiotik dengan Swamedikasi Ibu Rumah Tangga Yang Menggunakan Antibiotik di Kelurahan Kajen Kabupaten Pekalongan.

Pengetahuan merupakan domain yang sangat penting untuk terbentuknya tindakan seseorang. Berdasarkan pengalaman dan penelitian ternyata perilaku yang didasari pengetahuan akan lebih langgeng daripada perilaku yang tidak didasari oleh pengetahuan. Sedangkan menurut WHO (1984) bahwa yang menyebabkan seseorang itu berperilaku karena adanya 4 alasan pokok yaitu pemikiran dan perasaan, acuan dan referensi dari seseorang, sumber daya, dan sosio budaya. Bentuk dari pemikiran dan perasaan salah satunya adalah pengetahuan. Seseorang akan berperilaku didasarkan beberapa pertimbangan yang diperoleh dari tingkat pengetahuannya (Notoatmodjo, 2010).

Pengetahuan merupakan bagian penting dalam mempengaruhi perilaku kesehatan. Upaya-upaya ini menjadikan setiap individu atau kelompok akan berusaha merubah sikap dan perilaku kesehatannya. Notoatmodjo (2007) bahwa pengetahuan merupakan strategi perubahan perilaku yang penting untuk menimbulkan kesadaran dan akhirnya berperilaku sesuai dengan pengetahuan yang dimilikinya.

Responden yang mempunyai pengetahuan baik dan perilaku swamedikasi yang tepat dalam pengobatan mandiri menunjukkan bahwa pengetahuan yang dimiliki responden berpengaruh terhadap perilaku responden terutama dalam penggunaan Antibiotik. Responden yang mempunyai pengetahuan baik tentang antibiotik dalam pengobatan mandiri dapat disebabkan salah satunya karena adanya motivasi responden untuk menjaga kesehatan.

Dari hasil uji multivariat regresi logistic didapatkan hasil bahwa factor pengetahuan menjadi factor penentu perilaku swamedikasi pada ibu. Hal ini dapat disebabkan karena ibu yang pengetahuan yang baik memungkinkan untuk melakukan analisa terhadap kebutuhan fisik dan keluarganya dan memilih upaya-upaya untuk meningkatkan aktifitas peningkatan kesehatan.

\section{Alasan Pemilihan Antibiotik}

Persentase responden sebagian besar memiliki Alasan pemilihan yang baik tentang antibiotik 54.7\%. Dengan jumlah responden yang melakukan swamedikasi sebanyak $\quad 10.4 \%$ sedangkan jumlah responden yang tidak melakukan swamedikasi sebanyak 
Faktor-faktor yang Berpengaruh....... (Ady Restiyono)

89.6\%.. Analisa bivariat menggunakan

Chi-Square menunjukkan bahwa dengan nilai $\alpha=0,05$ diperoleh nilai $\mathrm{p}=$ 0,000 maka dapat disimpulkan terdapat pengaruh Alasan pemilihan Antibiotik dengan Swamedikasi Ibu Rumah Tangga Yang Menggunakan Antibiotik di Kelurahan Kajen Kabupaten Pekalongan.

Ada berbagai hal yang melatarbelakangi ibu melakukan swamedikasi antibiotik, yaitu:

a. Biaya pengobatan yang mahal

Merupakan penilain konsumen dari murah sampai mahal dalam berobat ke dokter.

b. Kemudahan Pengobatan

Merupakan kecepatan proses memperoleh obat tanpa harus menunggu pemeriksaan dari dokter.

c. Pesan iklan

Merupakan esan dari perusahaan farmasi untuk menginformasikan obat dan manfaatnya bagi kesembuhan suatu penyakit.

d. Tingkat pendidikan

Merupakan ukuran tinggi rendahnya jenjang pendidikan yang dimiliki oleh ibu rumah tangga.

e. Informasi dari pihak lain

Merupakan informasi dari seseorang yang didasarkan pengalamannya dalam menggunakan suatu obat (Atmoko dan Kurniawati, 2009).
Disebutkan Oleh Niken bahwa seseorang melakukan swamedikasi dilatarbelakangi oleh pengalaman atau keluarga, pernah menggunakan sisa obat orang lain, menggunakan kopi resep dokter. Dan meningkatnya perilaku swamedikasi disebabkan karna perkembangan teknologi farmasi yang inivatif, jenis atau merk obat yang beredar telah diketahui atau dikenal oleh masyarakat luas. Berubahnya peraturan tentang obat dan farmasi. Kesadaran masyarakat akan pentingnya arti sehat.

Hal ini diperkuat dengan hasil kuesioner dimana ibu menggunakan antibiotik karena alas an saran dari keluarga/ teman 56\%, ibu menggunakan antibiotik karena alasan kesembuhan pada pengobatan sebelumnya $82.7 \%$. bentuk dukungan dari orang-orang sekitar dalam perilaku swamedikasi menjadi factor pendorong dalam penggunaan antibiotik secara mandiri. Menurut Green (2000) dukungan merupakan salah satu dari beberapa hal yang menjadi faktor pendorong (Reinforcing factor) dalam perubahan perilaku seseorang. Sehingga dengan adanya dukungan dari keluarga dalam alas an pemilihan antibiotik diharapkan menjadi faktor pendorong bagi responden untuk berperilaku baik dalam 
Jurnal Promosi Kesehatan Indonesia Vol. 11 / No. 1 / Januari 2016

penggunaan antibiotik dalam

swamedikasi.

\section{Sumber Informasi}

Persentase responden sebagian besar memiliki Alasan pemilihan yang baik tentang antibiotik $60.3 \%$. Dengan jumlah responden yang melakukan swamedikasi sebanyak $\quad 10.5 \%$ sedangkan jumlah responden yang tidak melakukan swamedikasi sebanyak 89.5\%.. Analisa bivariat menunjukkan bahwa dengan nilai $\alpha=0,05$ diperoleh nilai $\mathrm{p}=0,000$ maka dapat disimpulkan terdapat pengaruh Sumber Informasi dalam pemilihan Antibiotik dengan Swamedikasi Ibu Rumah Tangga Yang Menggunakan Antibiotik di Kelurahan Kajen Kabupaten Pekalongan.

Berdasarkan pengertian dari Swamedikasi sendiri yang merupakan perilaku untuk mengatasi sakit ringan sebelum mencari pertolongan ke petugas atau fasilitas kesehatan. Swamedikasi sendiri berada dalam konteks mengobati diri untuk meringankan penderitaan atau sakit. Berlandaskan pada Permenkes No. 919/MENKES/PER/X/1993 secara sederhana swamedikasi didefinisikan sebagai upaya seseorang dalam mengobati gejala sakit tanpa berkonsultasi dengan dokter terlebih dahulu, namun bukan berarti tanpa petunjuk medis, justru pasien harus 
Faktor-faktor yang Berpengaruh....... (Ady Restiyono)

dipertanggung jawabkan untuk pengobatan sendiri ${ }^{41}$

Dampak positif dari swamedikasi antara lain: Pencegahan maupun pengobatan yang lebih dini dan biaya yang lebih terjangkau dan cepat. Namun memiliki dampak negative terkait dengan pengobatan menggunakan antibiotik yang kurang rasional yang disebabkan karna masyarakat awam tidak mengetahui latar belakang pasti sebuah penyakit disebabkan oleh bakteri, virus, atau parasit lainnya. Sedangkan dalam penggunaan antibiotik hanya efektif jika penyebab penyakit adalah bakteri.

\section{Swamedikasi Antibiotik}

Hasil penelitian menunjukkan persentase responden sebagian besar melakukan pengobatan dengan petunjuk medis yaitu $60.3 \%$. Dari distribusi jawaban responden mengenai perilaku swamedikasi bahwa sebagian besar responden bertanya terlebih dahulu pada apoteker saat membeli antibiotik sebanyak $97 \%$ responden.

Disinilah peran Farmasi Apoteker untuk membimbing dan memilihkan obat yang tepat. Pasien dapat meminta informasi kepada apoteker agar pemilihan obat lebih tepat. Selain apoteker, tenaga farmasi lain seperti asisten apoteker mempunyai peran penting dalam menyampaikan informasi obat kepada masyarakat. Seperti penyampaian informasi tentang penggunaan obat secara tepat, aman dan rasional. Informasi yang diberikan harus benar, jelas dan mudah dimengerti serta cara penyampaiannya disesuaikan dengan kebutuhan, selektif, etika, bijaksana dan hati-hati. Informasi yang diberikan kepada pasien sekurangkurangnya meliputi: cara pemakaian obat, cara penyimpanan obat, jangka waktu pengobatan, makanan/ minuman/ aktifitas yang hendaknya dihindari selama terapi dan informasi lain yang diperlukan (Anief, 1997).

\section{SIMPULAN}

Praktik swamedikasi antibiotik pada ibu rumah tangga diketahui lebih banyak yang tidak melakukan swamedikasi antibiotik dibandingkan yang melakukan swamedikasi antibiotik (41\%).

Variabel yang berpengaruh terhadap swamedikasi antibiotik pada ibu rumah tangga adalah pengetahuan tentang antibiotik $(\mathrm{OR}=5.307, \mathrm{p}=0,000)$, berarti pengetahuan yang baik mempunyai kemungkinan 5.307 kali tidak melakukan swamedikasi antibiotik dibandingkan dengan pengetahuan yang kurang baik, dan sumber informasi pemilihan antibiotik $(\mathrm{OR}=29,94, \quad \mathrm{p}=0.0005)$, berarti yang 
Jurnal Promosi Kesehatan Indonesia Vol. 11 / No. 1 / Januari 2016

memiliki sumber informasi baik mempunyai kemungkinan 29,94 kali tidak melakukan swamedikasi antibiotik dibandingkan dengan yang memiliki sumber informasi kurang baik.

Variabel yang berhubungan dengan swamedikasi antibiotik pada ibu rumah tangga yaitu pengetahuan tentang antibiotik $(\mathrm{p}=0,000)$, alasan pemilihan antibiotik $(p=0,000)$ dan sumber informasi pemilihan antibiotik $(\mathrm{p}=0,000)$. Variabel yang tidak berhubungan dengan swamedikasi antibiotik pada ibu rumah tangga adalah usia $(\mathrm{p}=0,112)$, pendidikan $(\mathrm{p}=0,831)$, jumlah anggota keluarga $(\mathrm{p}=0,165)$, pekerjaan $(\mathrm{p}=0,982)$ dan pendapatan $(\mathrm{p}=0,572)$.

\section{KEPUSTAKAAN}

Anief, M. Ilmu Meracik Obat. Gajah Mada University Press. Yogyakarta. 1997

Atmoko dan Kurniawati. Swamedikasi Sebuah Respon Realistik Perilaku Konsumen Di Masa Krisis. Jurnal Bisnis dan Kewirausahaan. 2009.

Badan Pusat Statistik and ORC Makro. Survei Demografi dan Kesehatan Indonesia 2007-2010. BPS and ORC Macro. Jakarta. 2011.

Green, L.W. dan Marshall W.K. Health Promotion Planning An Educational and Environmental Approach. Second Edition. London : Mayfield Publishing Company. 2000.

Keputusan Mentri Kesehatan Republik Indonesia Nomor 1332/MENKES/SK/X/2002/ tentang Perubahan atas Peraturan Mentri No: 922/MENKES/PER/X/1993 tentang Ketentuan dan Tata Cara Pemberian Izin Apotek.

Notoatmodjo, S. 2007. Promosi Kesehatan dan Perilaku. Rineka Cipta.

Notoadmodjo S. Ilmu Perilaku Kesehatan. Jakarta: Bineka Cipta; 2010

Notoatmodjo, Soekidjo, Pendidikan dan Perilaku Kesehatan. Jakarta: PT. Rineka Cipta. 2003

Shankar, P.R., dkk. Self-Medication and Non-Doctor Prescription Practices in Pokhara Valley, Western Nepal: a questionnaire-based study. BMC Family Practice : 2002. (http://biomedcentral.org).

WHO. The Role of The Pharmacist in SelfCare and Self-Medication. The Netherlands. 1998. 
Faktor-faktor yang Berpengaruh....... (Ady Restiyono) 